\title{
p53 overexpression in Ewing's sarcoma/ primitive neuroectodermal tumour is an uncommon event
}

D C Mangham, A Cannon, X Q Li, S Komiya, M C Gebhardt, D S Springfield, A E Rosenberg, H J Mankin
Department of Orthopaedic

Surgery, Orthopaedic Research

Laboratories,

Massachusetts

General Hospital,

Boston,

MA 02114, USA

D C Mangham

A Cannon

X Q Li

$S$ Komiya

M C Gebhardt

D S Springfield

H J Mankin

Department of Pathology

D C Mangham

A E Rosenberg

Correspondence to: Dr D C Mangham, Department of Pathology, Medical School, University of Birmingham, Edgbaston, of Birmingham, Edgbast

Accepted for publication 20 January 1995

\begin{abstract}
Aim-To determine the presence of p53 overexpression in Ewing's sarcoma/primitive neuroectodermal tumours (ETs) and to assess whether p53 accumulation has any prognostic value.

Methods-From a prospectively compiled database of 76 patients with ETs, suitable tumour tissue was available for 38 . The monoclonal antibody pAb1801 was used to detect p53 nuclear protein overexpression. Results-Nuclear staining was detected in the tumours of three $(8 \%)$ of the 38 patients. Where tumours stained positively, over $10 \%$ of the tumour nuclei were postively stained. All three patients whose tumours overexpressed p53 died and in a relatively short time compared with the patients who did not overexpress p53 (mean 3.7 months compared with a mean of 38.7 months in the p53 negative group). Conclusion-Overexpression of p53 in ETs is an uncommon event. Overexpression of p53 has repeatedly been shown to correlate closely with p53 point missense mutations and therefore this oncogenic event appears not to be of primary pathogenic importance in ETs. There is a tentative indication that those uncommon ETs in which p53 overexpression can be detected may behave more aggressively.

(f Clin Pathol: Mol Pathol 1995;48:M79-M82)
\end{abstract}

Keywords: p53, Ewing's sarcoma, immunohistochemistry.

The p53 nuclear phosphoprotein is a transcription factor first reported in $1979 .{ }^{1}$ Wildtype p53 modulates cell cycle arrest in late G1 to phase inhibit oncogene mediated transformation $^{23}$ and controls radiation induced apoptosis. ${ }^{45}$ The p53 gene is frequently mutated in a wide variety of human tumours. ${ }^{6-15}$ Structural rearrangements, deletions and point mutations result in the loss of normal p53 function. ${ }^{710121416} \mathrm{~A}$ number of studies have shown a close correlation between p53 missense point mutations and p53 protein detection by immunohistochemistry. ${ }^{17-23}$ These observations are in accordance with the finding that most point mutated p53 proteins have prolonged half-lives, ${ }^{24}$ permitting $\mathrm{p} 53$ protein accumulation. Conversely, wild-type p 53 protein has a very short half-life ${ }^{25}$ and cannot be detected immunohistochemically.

Ewing's sarcoma and primitive neuroectodermal tumours (PNET) (ETs) are closely related bone and soft tissue tumours of childhood and early adult life. They share a common genomic translocation-11:22 (q24:q12) ${ }^{26}$-in over $90 \%$ of cases. A recent report ${ }^{23}$ found that the p53 gene was only rarely mutated in these tumours. This study looked for overexpression of p53 protein in ETs from 38 patients using immunohistochemistry.

\section{Methods}

A database of a cohort of 78 patients with Ewing's sarcoma/PNET was prospectively compiled from the medical records in the Orthopaedic department and the Medical Records of the Massachusetts General Hospital, Boston. Full clinical details, including age, sex, tumour location, clinical stage at diagnosis, treatment

\begin{tabular}{|c|c|c|c|c|}
\hline \multirow{2}{*}{$\begin{array}{l}\text { Patient } \\
\text { No. }\end{array}$} & \multicolumn{3}{|l|}{ Tissue } & \multirow{2}{*}{$\begin{array}{l}\text { p53 } \\
\text { overexpression }\end{array}$} \\
\hline & $B$ & $R$ & $M$ & \\
\hline 1 & $\times(1)$ & \multirow{4}{*}{$\times(1)$} & \multirow{4}{*}{$\times(2)$} & $=$ \\
\hline 2 & & & & - \\
\hline 3 & $\times(1)$ & & & - \\
\hline $\begin{array}{l}4 \\
5\end{array}$ & $\begin{array}{l}\times(1) \\
\times(1)\end{array}$ & & & - \\
\hline 6 & & $\times(1)$ & \multirow{3}{*}{$\times(2)$} & - \\
\hline 7 & & $\times(1)$ & & $\overline{-}$ \\
\hline 8 & & $\times(1)$ & & - \\
\hline 9 & $\times(3)$ & & & - \\
\hline 10 & $\times(1)$ & & & - \\
\hline \multirow[t]{2}{*}{11} & $\times(3)$ & & \multirow{3}{*}{$\times(1)$} & $\stackrel{+}{-}$ \\
\hline & & $x(2)$ & & $\overline{-}$ \\
\hline \multirow{2}{*}{13} & \multirow[b]{2}{*}{$\times(1)$} & $\times(1)$ & & - \\
\hline & & $\times(2)$ & & - \\
\hline 14 & & $\begin{array}{l}\times(2) \\
\times(2)\end{array}$ & & - \\
\hline $\begin{array}{l}15 \\
16\end{array}$ & & $\begin{array}{l}\times(1) \\
\times(1)\end{array}$ & & $\overline{-}$ \\
\hline $\begin{array}{l}16 \\
17\end{array}$ & $\times(1)$ & $\times(1)$ & & - \\
\hline 18 & $\times(1)$ & & & - \\
\hline 19 & & $\times(1)$ & & - \\
\hline 20 & $\times(1)$ & & & - \\
\hline 21 & $\times(3)$ & & & - \\
\hline 22 & $\times(1)$ & & & + \\
\hline 23 & $\times(1)$ & & & - \\
\hline $\begin{array}{l}24 \\
25\end{array}$ & $x(1)$ & $\times(2)$ & & $\overline{-}$ \\
\hline 26 & $\times(2)$ & & & - \\
\hline 27 & $\times(2)$ & & & - \\
\hline $\begin{array}{l}28 \\
20\end{array}$ & $\times(1)$ & & & - \\
\hline 29 & $\times(1)$ & 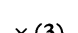 & & - \\
\hline $\begin{array}{l}30 \\
31\end{array}$ & $\times(1)$ & $\times(3)$ & & $\overline{-}$ \\
\hline $\begin{array}{l}31 \\
32\end{array}$ & $\lambda(1)$ & $\times(2)$ & & - \\
\hline 33 & $\times(2)$ & & & - \\
\hline $\begin{array}{l}34 \\
35\end{array}$ & $\times(2)$ & $\times(1)$ & & $\overline{-}$ \\
\hline 36 & $\times(1)$ & & $\times(1)$ & - \\
\hline & (.) & & $\times(4)$ & - \\
\hline $\begin{array}{l}37 \\
38\end{array}$ & $\begin{array}{l}\times(1) \\
\times(4)\end{array}$ & & & $\bar{t}$ \\
\hline
\end{tabular}

*Values in parentheses denote the number of tissue block examined.

$\mathrm{B}=$ biopsy; $\mathrm{R}=$ resection; $\mathrm{M}=$ metastasis 


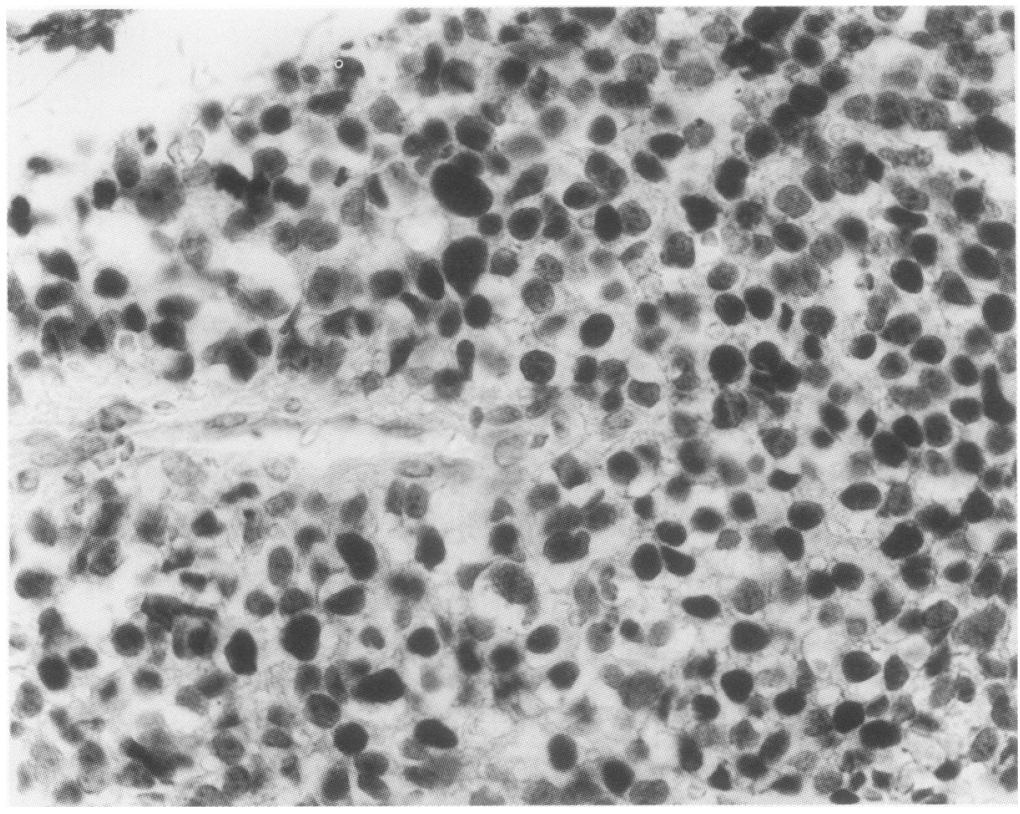

Figure 1 Ewings tumour overexpressing $p 53$ protein. Immunostained with $p A b 1810$ and lightly counterstained with haematoxylin. Note pale nuclei of vessel endothelium compared with positively immunostained tumour nuclei.

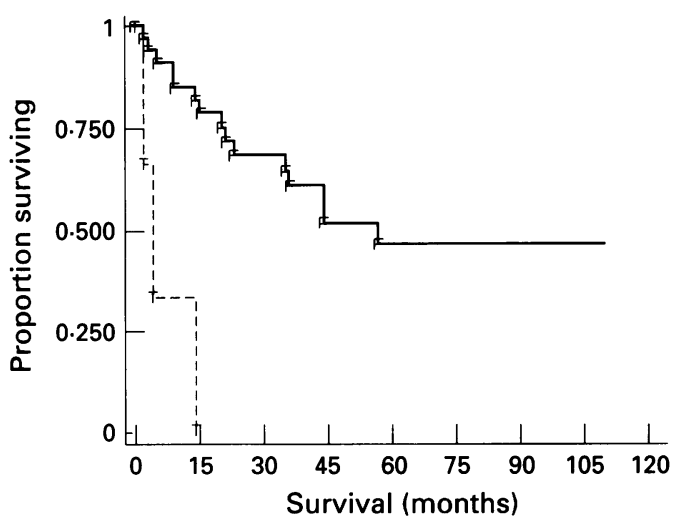

Figure 2 Kaplan-Meier curves for overall survival of patients with Ewing's tumour.

$T=$ patients with tumours overexpressed $p 53$ protein; $F=$ patients whose tumours did not overexpress $p 53$ protein.

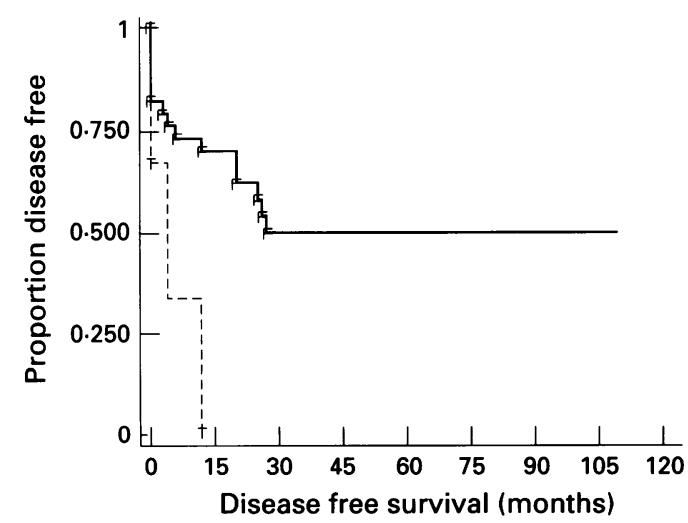

Figure 3 Kaplan-Meier curves for disease free survival

of patients with Ewing's tumour.
$T=$ patients whose tumours overexpressed $p 53$ protein; $F=$ patients whose tumours did not overexpress $p 53$ protein.

history, dates of metastases, local recurrence, and death, were available for all patients. The study period was from 1982 to 1993. All patients received a course of chemotherapy after the diagnostic biopsy and before tumour resection. Chemotherapy comprised courses of the drugs vincristine, adriamycin, cyclophosphamide according to the protocol of the paediatric oncology group (POG \#8850 and \#8346). Haematoxylin and eosin stained sections of tumour tissue were reviewed and adequate tumour was available for 38 of the 78 patients in the original cohort.

The haematoxylin and eosin stained archival slides of the study population were reviewed and tissue blocks were retrieved where adequate tissue was available. Multiple blocks of tumour were retrieved for some patients' tumours. All of the material had been routinely fixed in $10 \%$ formalin and, where appropriate, decalcified in a $5 \% \mathrm{HCl}$ and EDTA mixture. Previous studies have shown that careful decalcification of tissue does not impair immunostaining. ${ }^{27} 28$ Seventy blocks of tissue were selected-that is, multiple tumour blocks were selected in some patients. In some cases this represented several blocks from a single surgical procedure and/or biopsy. Details of the numbers of blocks and whether these were biopsy, resection or metastatic tumour are presented in the table. Sections $5 \mu \mathrm{m}$ thick were cut, deparaffinised and incubated with the monoclonal antibody pAb 1801 (Cambridge Biochemicals Research Inc.) at a 1 in 500 dilution in phosphate buffered saline (PBS) for one hour at room temperature. Primary antibody was visualised by the avidinbiotin complex technique (Vector Labs, Burlingame, California, USA). The peroxidase reaction was developed using the 3-amino-9ethylcarbazole (AEC) kit (Vector Labs, Catalog number SK 4200). All cases were immunostained twice. For negative control, primary antibody was substituted with a monoclonal antibody against cytomegalovirus (Dako-CMV, DDG9, CCH2, Dako, Glostrup, Denmark). Tumours were declared positive if any of the tumour cell nuclei stained positively. Figure 1 illustrates positive nuclear staining.

Kaplan-Meier curves were generated to correlate the results of the immunostaining with patient outcome (that is, disease free survival and overall survival).

\section{Results}

Three $(8 \%)$ of the 38 patients' tumours examined showed positive staining for $\mathrm{p} 53$. In all three cases over $10 \%$ of tumour nuclei were p53 positive. In one of these cases (patient 11) multiple blocks of tissue from different surgical specimens (pre- and post-chemotherapy) containing tumour were available; only the prechemotherapy biopsy tissue (three blocks of tissue) stained positively for $\mathrm{p} 53$. In the other two positive cases (patients 22 and 38 ) only pre-chemotherapy biopsy tissue was available. When more than one block of tissue from a tumour specimen was immunostained, the result was consistent throughout the specimen (all positive or all negative)-that is, tumours were sampled and were homogeneous for their p53 expression. Negative cases showed no nuclear staining. All cases showed reproducible results on repeat immunostaining. The results are summarised in the table. 
The three patients whose tumours overexpressed p53 fared considerably worse. Patient 11 died 13.9 months after diagnosis (presented with stage 2 disease), patient 22 died 4.3 months after diagnosis (presented with stage 2 disease) and patient 38 died 2.0 months after diagnosis (presented with stage 3 disease). The results of the Kaplan-Meier analysis show that the overall mean survival was 38.7 months and 3.7 months $(p<0.0001)$ for patients with negative and positive p53 staining tumours, respectively; the mean disease-free survival was 27.2 months and 3.5 months $(p=0.02)$ for patients with negative and positive $\mathrm{p} 53$ staining tumours, respectively. Figures 2 and 3 show the overall and disease free survival curves for these two groups of patients. Two of the p53 positively staining ETs were pelvic and when the pelvic tumours only (13 cases) were analysed, overall survival was statistically different between the two groups (positive group mean three months, negative group mean 25.4 months; $p<0 \cdot 02$ ), but disease free survival was not (positive group mean two months, negative group mean 15 months; $\mathrm{p}<0 \cdot 24)$. The overall survival of stage 2 ETs was also significantly worse in the $\mathrm{p} 53$ positive group (positive group mean nine months, negative group mean 43.6 months; $\mathrm{p}<0.0007)$.

\section{Discussion}

Immunohistochemically detected p53 overexpression correlates closely with the detection of missense point mutations in the p53 gene. ${ }^{17-23}$

There have only been a few studies in which p53 mutations have been sought in ETs. Seven, five, and two ETs have been investigated at the DNA level and no mutations were found..$^{142930}$ Kovar et $a l^{23}$ reported an incidence of two mutations (both point missense) in $37(5 \%)$ ETs analysed by single strand conformational polymorphism (SSCP) and sequencing. Of these 37 tumours, 26 were analysed for overexpression by immunohistochemistry and only the two tumours in which mutations were detected by SSCP stained positively for p53 overexpression.

In our series we used an antibody (pAb1801) which binds human wild-type and mutant p53 protein. Of 38 ETs (some of which had multiple tissue samples), the incidence of p53 overexpression was $8 \%$ (three of 38 ) and is similar to that found by Kovar et al..$^{23}$ Patient 11 had three specimens available for study (biopsy, resection and metastases) and only the biopsy specimen stained positively for p53 protein; there appears to have been a change in the p53 status of this tumour after the course of chemotherapy (three months).

Overexpression of $\mathrm{p} 53$, presumably due to point missense mutation, is an uncommon event in ETs. This low incidence suggests that p53 point missense mutations are not of primary pathogenic significance in ETs. This, however, does not mean that some disruption of the p53 pathway is not of importance in the pathogenesis of ETs. For example, mdm-2 (the product of which binds and inactivates p53) has been found to be amplified in a number of sarcomas. However, mdm-2 amplification was sought in 37 ETs and not found in any of these tumours. ${ }^{23}$

The sample size in this study is relatively small and therefore the statistical analysis should be interpreted with caution. However, there are striking differences in the survival of the three patients with positively immunostained tumours and those with negatively immunostained tumours. The mean period from diagnosis to death was 6.7 months, compared with the group as a whole ( 30 presented with stage 2 disease and eight with stage 3 disease) in whom the mean period from diagnosis to death was $\mathbf{5 5}$ months. It is possible that there are other factors with which p53 overexpression may be correlated, although a statistical difference in overall survival was maintained when only pelvic tumours were analysed and when only stage 2 tumours were analysed. However, the number of $\mathrm{p} 53$ positive cases remains too small for a rigorous statistical analysis to exclude all potential confounding factors and it cannot be concluded that p53 overexpression is an independent indicator of tumour behaviour.

In summary, we have looked for p53 overexpression using immunohistochemistry and found that overexpression (and, by inference, point mutation of the p53 gene) is an uncommon event in ETs. In addition, we have preliminary data suggesting that those few tumours that do overexpress p53 behave more aggressively.

We thank C Trahan for expert technical assistance. This study was partially supported by the Council for Tobacco Research, USA (grant SA005). DC Mangham is a Wechsler Fellow.

1 Lane DP, Crawford LV. T-antigen is bound to host protein in SV-40 transformed cells. Nature 1979;278:261-3.

2 Eliyahu D, Michalovitz D, Eliyahu S, Pinhasi-Kimhi O Oren $\mathrm{M}$. Wild type p53 can inhibit oncogene-mediated focus formation. Proc Natl Acad Sci USA 1989;86:8763-7.

3 Finlay CA, Hinds PW, Levine AJ. The p53 proto-oncogene can act as a suppressor of transformation. Cell 1989;57: can act as a

4 Lowe SW, Schmitt EM, Smith SW, Osborne BA, Jacks T. p53 is required for radiation-induced apoptosis in mouse thymocytes. Nature 1993;362:847-9.

5 Clarke AR, Purdie CA, Harrison DJ, Morris RG, Bird CC, Hooper ML, et al. Thymocyte apoptosis induced by p53dependent and independent pathways. Nature 1993;362 849-52.

6 Hollstein M, Sidransky D, Vogelstein B, Harris CC. p53 mutations in human cancer. Science 1991;253:49-53.

7 Nigro JM, Baker SJ, Preisinger AC, Jessup JM, Hostetten $\mathrm{P}$, Cleary K, et al. Mutations of the p53 gene occur in diverse human tumor types. Nature 1989;342:705-8.

8 Iggo R, Gatter K, Bartek J, Lane D, Harris AL. Increased expression of mutant forms of p53 oncogene in primary expression of mutant forms of p53 oncer
lung cancer. Lancet 1990;335:675-9.

9 Chiba I, Takahashi T, Nau MM, D'Amico D, Curiel DT, Mitsudomi T, et al. Mutations in the p53 gene are frequent in primary, resected non-small cell lung cancer. Oncogene 1990;5:1603-10.

10 Baker SJ, Fearon ER, Nigro JM, Hamilton SR, Preisinger $\mathrm{AC}$, Jessup JM, et al. Chromosome 17 deletions and p53 gene mutations in colorectal carcinomas. Science 1989, 244:217-21.

11 Campo E, Calle-Martin O, Miguel R, Palacin A, Romero $M$, Fabregat $V$, et al. Loss of heterozygosity of $\mathrm{p} 53$ gene and p53 protein expression in human colorectal carcinomas. p53 protein expression in hum
Cancer Res 1991;51:4436-42.

12 Prosser J, Thompson AM, Cranston G, Evans HJ. Evidence that p 53 behaves as a tumour suppressor gene in sporadic that p53 behaves as a tumour suppressor
breast tumors. Oncogene $1990 ; 5: 1573-9$.

13 Masuda H, Miller C, Koeffler HP, Battifora H, Cline MJ. Rearrangement of the p53 gene in human osteogenic sarcomas. Proc Natl Acad Sci USA 1987;84:7716-19.

14 Mulligan LM, Matlashlewski GJ, Scrable HJ, Cavence WK. Mechanisms of p53 loss in human sarcomas. Proc Nat Acad Sci USA 1990;87:5863-7.

15 Stratton MR, Moss S, Warren W, Patterson H, Clark J, Fisher C, et al. Mutation of the p53 gene in human sof tissue sarcomas: association with abnormalities of the $\mathrm{Rb}$ gene. Oncogene 1990;5:1297-301. 
16 Takahashi T, Nau MM, Chiba I, Birrer MJ, Rosenberg RK, Vinousur $M$, et al. p53: A frequent target for genetic abnormalities in lung cancer. Science 1989;246:491-4.

17 Davidoff AM, Humphrey PA, Iglehart JD, Marks JR. Genetic basis for p53 overexpression in human breast cancer. Proc Natl Acad Sci USA 1991;88:5006-10.

18 Bartek J, Iggo R, Gannon J, Lane DP. Genetic and immunochemical analysis of mutant p53 in human breast cancer cell lines. Oncogene 1990;5:893-9.

19 Bartek J, Bartkova J, Vojtesek B, Staskova Z, Lukas J, Rejthar $\mathrm{A}$, et al. Aberrant expression of the p53 oncoprotein is a common feature of a wide spectrum of human maligcommon feature of a wide spectrum

20 Varley JM, Brammar WJ, Lane DP, Swallow JE, Dolan C, Walker RA. Loss of chromosome 17 p13 sequences and mutation of p53 in human breast cancer. Oncogene 1991; 6:413-21.

21 Thor AD, Moore DH II, Edgerton SM, Kawasaki ES, Reihsaus E, Lynch HT, et al. Accumulation of p 53 tumor suppressor gene protein: An independent marker of prognosis in breast cancers. $\mathcal{F}$ Natl Cancer Inst 1992:84:138997.

22 Esrig D, Spruck CH, Nichols P, Cheuwun B, Steven K, Groshen $\mathrm{S}$, et al. p53 nuclear protein accumulation correlates with mutations in the p53 gene, tumor grade, and relates with mutations in the p53 gene, tumor grade, and
stage in bladder cancer. Am $\mathcal{F}$ Pathol 1993;143:1389-97.

23 Kovar H, Auinger A, Jug G, Aryee D, Zoubek A, SalzerKuntschik M, et al. Narrow spectrum of infrequent p53 mutations and absence of MDM2 amplification in Ewing's tumors. Oncogene 1993;8:2683-90.

24 Finlay CA, Hinds PW, Tan TH, Eliyahu D, Oren M, Levine AJ. Activating mutations for transformation by $\mathrm{p} 53$ produce a gene product that forms an hsc70-p53 complex with an altered half-life. Mol Cell Biol 1988;8:531-9.

25 Reihsaus E, Kohler M, Kraiss S, Oren M, Montenarh M. Regulations of the level of the oncoprotein p53 in nontransformed and transformed cells. Oncogene 1990;5:137trans
45.

26 Turc-Carel C, Aurias A, Mugneret F, Lizard S, Sidaner, Volk C, et al. Chromosome in Ewing's sarcoma. I. An
evaluation of 85 cases with remarkable consistency of $t(11$ : 22)(q24:q12). Cancer Genet Cytogenet 1988;32:229-38.

27 Devaney K, Vinh TN, Sweet DE. Small cell osteosarcoma of bone: An immunohistochemical study with differential diagnostic considerations. Hum Pathol 1993;24:1211-25.

28 Mukai K, Anzai M. Effects of decalcification on immunoperoxidase staining. Am f Surg Pathol 1986;10:41319.

29 Toguchida J, Yamaguchi T, Ritchie B, Beauchamp RL, Dayton SH, Herrera GE, et al. Mutation spectrum of the p53 gene in bone and soft tissue sarcomas. Cancer Res 1992;52:6194-9.

30 Miller CW, Aslo A, Tsay C, Slamon D, Ishizaki K, Toguchida J, et al. Frequency and structure of p53 rearrangements in human osteosarcoma. Cancer Res 1990; 50:7950-4. 